\title{
Digitaria insularis Management and Nematode Dynamics in Off-season Maize
}

\author{
Marcos Massuo Kashiwaqui \\ Dept. of Agrarian Science, State University of Maringá \\ Umuarama, Paraná, 87507-290, Brazil \\ Tel: +55-67-984290313Ｅ-mail: mkashiwaqui@yahoo.com.br \\ Claudia Regina Dias-Arieira (Corresponding author) \\ Dept. of Agrarian Science, State University of Maringá \\ Umuarama, Paraná, 87507-290, Brazil \\ Tel: +55-44-984033198Ｅ-mail: crdarieira@uem.br \\ João Paulo Matias \\ Dept. of Agronomy, State Central West University \\ Guarapuava, Paraná, 85040-167, Brazil \\ Tel: +55-44-99839-8317Ｅ-mail: jpmatias2@gmail.com
}

André A. Pazinato da Silva

Dept. of Agronomy, State Central West University

Guarapuava, Paraná, 85040-167, Brazil

Tel: +55-44-99899901Ｅ-mail: andrepazinato0@ gmail.com

José Cristimiano dos Santos Neto

Dept. of Agronomy, State Central West University

Guarapuava, Paraná, 85040-167, Brazil

Tel: +55-42-991092757_E-mail: neto.buri@hotmail.com 
José Junior Severino

Dept. of Agrarian Science, State University of Maringá

Umuarama, Paraná, 87507-290, Brazil

Tel: +55-44-999290884Ｅ-mail: jjseverino@uem.br

Cleber Daniel de Goes Maciel

Dept. of Agronomy, State Central West University

Guarapuava, Paraná, 85040-167, Brazil

Tel: +55-44-991153676_E-mail: cmaciel@unicentro.br

Received: Apr. 22, $2020 \quad$ Accepted: June 4, $2020 \quad$ Published: June 8, 2020

doi:10.5296/jas.v8i2.17186 URL: https://doi.org/10.5296/jas.v8i2.17186

\begin{abstract}
Maize stands out as one of the most important crops in succession to soybean in tropic countries. However, the susceptibility of both crops to nematodes, can cause a continuous increase in the nematode population, especially in areas where there is the occurrence of weeds susceptible to the parasites. Thus, the objective was to evaluate the nematodes dynamics in a growing area with off-season maize under chemical weed management. The experiment was installed at Tuneiras do Oeste County, Brazil, designed in randomized blocks, with seven treatments and five replications, constituted by sourgrass (Digitaria insularis) management systems with glyphosate associated to herbicides inhibitors of the enzyme acetyl-CoA carboxylase (ACCase) and auxin-mimetic, and complement with glyphosate + atrazine + tembotrione in post-emergence. The effect of treatments on Pratylenchus spp. population was observed in roots and soil rhizosphere soil of $D$. insularis and in maize roots. Glyphosate application followed by glyphosate + atrazine was inefficient in controlling sourgrass. Management system with glyphosate + clethodim + 2.4-D followed by glyphosate + atrazine + tembotrione reduced the Pratylenchus spp. population in sourgrass, but any management system repeated this effect in maize. Management systems of $D$. insularis with associations of glyphosate + clethodim; glyphosate + clethodim + 2.4-D and glyphosate + fenoxaprop-p-ethyl, all followed by glyphosate + atrazine + tembotrione, showed excellent control level of sourgrass without affecting plant height, grain and rank numbers and grain yield. It is concluded that the management system using herbicides association controlled sourgrass and may interferer on Pratylenchus spp. population.
\end{abstract}

Keywords: herbicide association, Pratylenchus spp., sourgrass, Zea mays 


\section{Introduction}

Maize is a cereal grown almost everywhere in the world, whose derivatives are commonly used in human and animal nutrition and biofuel production. In Brazil, maize has become an important growing option in succession with soybean, being called off-season maize ("safrinha"), which is of an extemporaneous nature. This practice arose due to the need to occupy the soil during the off-season and to take advantage of the idle production structure, which can generate extra income for the grower (Gonçalves et al., 1999). The soybean-maize succession system brings a series of advantages, by inserting plants from different botanical families, with different root systems, which make it possible to cover the soil practically all year round (Garcia et al., 2013). Added to this, the advantage of being susceptible to different pests and diseases, reducing the multiplication of these organisms during consecutive cycles.

Despite these advantages, the system has an important limitation, which is the common susceptibility of the two crops to some nematodes, especially Pratylenchus brachyurus, whose reproduction factor can be quite high in soybean and maize (Inomoto, 2011; Favoreto et al., 2019), and in numerous grass species, forage or not, grown in crop rotation, including plants of the genus Panicum and Urochloa (Inomoto et al., 2007; Dias-Arieira et al., 2009; Queiróz et al., 2014), and sorghum and millet (Inomoto et al., 2006). Added to these, the susceptibility to common weeds in the areas of soybean-maize succession, with emphasis on the sourgrass (Digitaria insularis) (Belle et al., 2015; Matias et al., 2018), considered one of the main invaders in the soybean-maize system, due to resistance to herbicides (Pereira et al., 2017; Costa et al., 2018).

For the management of nematodes, different practices must be adopted, such as the choice of resistant genotypes, with less chance of reproduction for the nematode, the planning of crop rotation, including non-host species or antagonists, in addition to the adequate control of weeds, which multiply the nematode (Favoreto et al., 2019).

The main strategy used in the management of weeds, in areas of maize growing, is the chemical control with herbicides. The association of different herbicides with varied mechanisms of action has been used to expand the action spectrum of applications and the efficiency on species resistant to one of the herbicides involved in the application (Nicolai and Christoffoleti, 2016). Thus, it is possible that repetitive use of mixtures of herbicides induce changes in the abundance of nematode populations living in the growing environment.

Johnson et al. (1975) found that herbicide applications did not significantly affect the populations of Meloidogyne incognita, P. brachyurus and Pratylenchus zeae in cotton, maize, peanut and soybean crops. However, some of these substances can influence the hatching and reproduction of nematodes (Wong et al., 1993; Levene, 1995). Glyphosate, for example, did not affect the population of Heterodera glycines, but the herbicides chlorimurom-ethyl in association with lactofen promoted reductions of this nematode in soybean crops (Barbosa et al., 2014). 


\section{Ml Macrothink}

Given the above, the hypothesis arose that the application of the herbicide glyphosate, in addition to controlling weeds, may have effects on the nematode population. Therefore, the objective was to evaluate the systems of herbicide associations in the control of sourgrass and in the population dynamics of Pratylenchus spp. in D. insularis and off-season maize.

\section{Material and Methods}

\subsection{Characterization of Experimental Area}

The experiment was conducted, between March and August 2015, in a commercial growing area, under the coordinates $23^{\circ} 57^{\prime} 38.7^{\prime \prime} \mathrm{S}$ and $52^{\circ} 57^{\prime} 49.4^{\prime \prime} \mathrm{W}$, at an altitude of 353 meters. The region's climate is classified by Köeppen as Cfa, with hot summers, uncommon frosts and a tendency for concentrated rain in the summer months, without a defined dry season (Caviglione et al., 2000). The daily meteorological data of temperature (maximum and minimum) and rainfall recorded in the region during the conduction of the experiment is shown in Figure 1.

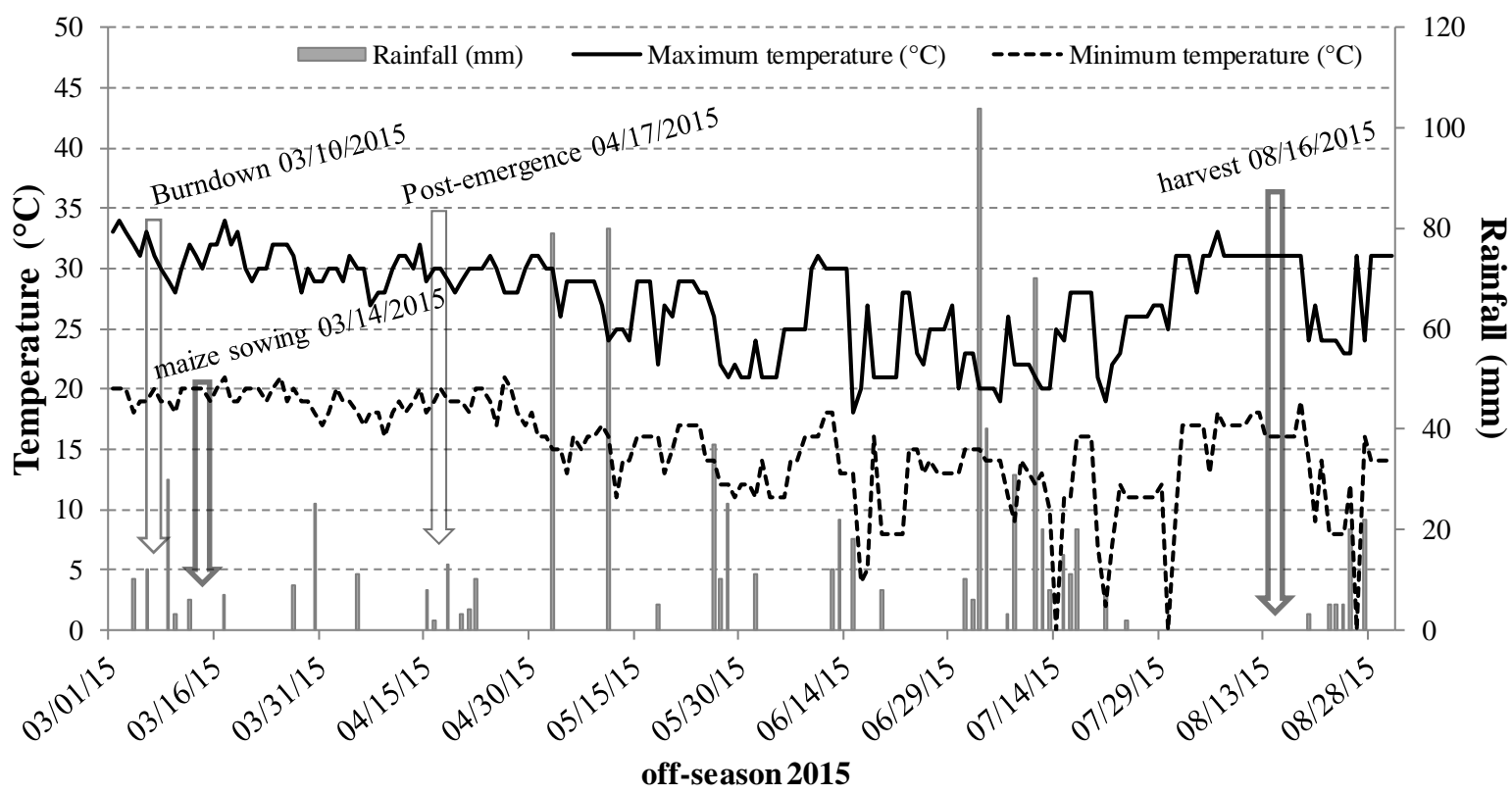

Figure 1. Daily meteorological data of temperature $\left({ }^{\circ} \mathrm{C}\right)$ and precipitation $(\mathrm{mm})$ during field experiment in off-season maize crop 2015. Tuneiras do Oeste - Paraná State, Brazil

The history of the area in recent years is a succession of soybean and off-season maize, the soil being composed of $48.56 \%$ sand, $9.28 \%$ silt and $42.16 \%$ clay. By chemical analysis, the following values were established: $\mathrm{pH}$ in $\mathrm{H}_{2} \mathrm{O}$ of $5.66 ; 7.28 \mathrm{cmol}_{\mathrm{c}} \mathrm{dm}^{-3}$ of CEC (effective cation exchange capacity); Base saturation (V\%) of $65.37 \% ; 10.39 \mathrm{mg} \mathrm{dm}^{-3}$ of phosphorus (P); $1.45 \mathrm{mg} \mathrm{dm}$ of potassium $\left(\mathrm{K}^{+}\right) ; 4.57 \mathrm{cmol}_{\mathrm{c}} \mathrm{dm}^{-3}$ of calcium $\left(\mathrm{Ca}^{+2}\right) ; 1.26 \mathrm{cmol}_{\mathrm{c}} \mathrm{dm}^{-3}$ of magnesium $\left(\mathrm{Mg}^{+2}\right)$. 


\subsection{Experiment Installation and Conduction}

The experiment was designed in randomized blocks, with seven treatments and five replications. The experimental units were composed of five lines of maize, spaced $0.45 \mathrm{~m}$ between the lines and $5 \mathrm{~m}$ in length. As a useful area, the two central lines were considered, with $0.5 \mathrm{~m}$ of the ends of the plots being considered a border area.

The treatments used were applied in two stages, the first in the burndown, and the second in the post-emergence application of maize and sourgrass plants (Table 1). In all applications, a backpack sprayer pressurized with $\mathrm{CO}_{2}$ was used, equipped with four TTi 110.15 nozzles (Teejet manufacturer), spaced $0.5 \mathrm{~m}$ apart, working pressure of $210 \mathrm{kPa}$ and application rate of $200 \mathrm{~L} \mathrm{ha}^{-1}$. The application time was always between 10:30 and 11:00 a.m.

The application of treatments in the burndown management of sourgrass occurred on $03 / 10 / 2015$, with perennialized plants ( \pm 15 tillers), right after the first root sampling and soil from the rhizosphere of the plants, for analyzes of the previous initial population of nematodes. Between the beginning and the end of the burndown application, the environmental conditions of air temperature, relative humidity and wind speed varied from 30.4 and $30.8{ }^{\circ} \mathrm{C}$, 66 and $68 \%$ and 1.0 to $1.6 \mathrm{~km} \mathrm{~h}^{-1}$, respectively. The application of treatments in the post-emergence of the crop was carried out on 04/17/2015, when the maize plants were in a phenological stage of six expanded leaves, and the sourgrass was completely controlled and without regrowth. The environmental conditions of air temperature, relative humidity and wind speed between the beginning and end of the post-emergence application, varied from 25.2 and $25.9{ }^{\circ} \mathrm{C}, 64$ and $65 \%$ and 1.1 to $1.6 \mathrm{~km} \mathrm{~h}^{-1}$, respectively, maintaining the same application times. 


\section{Ml Macrothink}

Table 1. Composition of herbicide treatments used in burndown and post-emergence applications for management of sourgrass (Digitaria insularis) in the off-season maize crop

\section{Doses}

Burndown (g ai or ae $\left.\mathrm{ha}^{-1}\right)^{/ 1}$

\section{Doses}

Post-emergence

(g ai or ae $\left.\mathrm{ha}^{-1}\right)^{1 / 1}$

\begin{tabular}{|c|c|c|c|c|}
\hline 1 & Weeded control & - & Weeded control & - \\
\hline 2 & Control without hoeing & - & Control without hoeing & - \\
\hline 3 & glyphosate $^{2}$ & 1440 & glyphosate $^{13}+$ atrazine $^{7}$ & $960+1000$ \\
\hline 4 & $\mathrm{GLF}^{/ 2}+$ clethodim $^{1 / 9}$ & $1440+192$ & $\mathrm{GLF}^{3}+$ atrazine $^{7}+$ tembotrione $^{/ 8 / 10}$ & $960+1000+84$ \\
\hline 5 & GLF $^{2}+$ fenoxapro-p-ethyl ${ }^{15}$ & $1440+220$ & 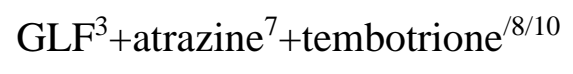 & $960+1000+84$ \\
\hline 6 & $\mathrm{GLF}^{/ 2}+$ clethodim $^{14}+2.4-\mathrm{D}^{16 / 9}$ & $1440+192+670$ & $\mathrm{GLF}^{3}+$ atrazine $^{7}+$ tembotrione $^{/ 8 / 10}$ & $960+1000+84$ \\
\hline 7 & $\mathrm{GLF}^{/ 2}+$ fenoxaprop $^{15}+2.4-\mathrm{D}^{16}$ & $1440+220+670$ & $\mathrm{GLF}^{3}+$ atrazine $^{7}+$ tembotrione $^{/ 8 / 10}$ & $960+1000+84$ \\
\hline
\end{tabular}

${ }^{/ 1} \mathrm{ai}=$ active ingredient; ae $=$ acid equivalent; ${ }^{/ 2}$ Roundup Original ${ }^{\mathrm{TM}}\left(360 \mathrm{~g} \mathrm{~L}^{-1}\right) ;{ }^{13}$ Roundup Transorb R ${ }^{\mathrm{TM}}\left(480 \mathrm{~g} \mathrm{~L}^{-1}\right) ;{ }^{/ 4} \operatorname{Select}^{\mathrm{TM}}\left(240 \mathrm{~g} \mathrm{~L}^{-1}\right) ;{ }^{15}$ Podium EW ${ }^{\mathrm{TM}}\left(110 \mathrm{~g} \mathrm{~L}^{-1}\right) ;{ }^{/ 6} \mathrm{DMA} 806$ $\mathrm{BR}^{\mathrm{TM}}\left(670 \mathrm{~g} \mathrm{~L}^{-1}\right) ;{ }^{17}$ Primoleo $^{\mathrm{TM}}\left(400 \mathrm{~g} \mathrm{~L}^{-1}\right){ }^{18} \operatorname{Soberan}^{\mathrm{TM}}\left(420 \mathrm{~g} \mathrm{~L}^{-1}\right)$; addition of $0.5 \% \mathrm{v} / \mathrm{v}$ of ${ }^{19}$ Lanzar $^{\mathrm{TM}}$ and ${ }^{110}$ Aureo ${ }^{\mathrm{TM}}$ adjuvants.

Three-way hybrid maize 2B712 PowerCore ${ }^{\mathrm{TM}}$ (Dow AgroSciences) was used, which has an early cycle and resistance to insects, as well as to the glyphosate and ammonium glufosinate herbicides. Sowing took place on 03/14/2015, using $0.45 \mathrm{~m}$ interline spacing and a final population of 41,000 plants $\mathrm{ha}^{-1}$. The seeds were previously treated with the insecticide thiametoxan $350 \mathrm{~g} \mathrm{~L}^{-1}$ (Cruiser ${ }^{\mathrm{TM}} 350 \mathrm{FS}$, Syngenta), in the dose of $100 \mathrm{ml}$ of the commercial product for 60,000 seeds. The area was fertilized with $268 \mathrm{~kg} \mathrm{ha}^{-1}$ of the formulated 6-24-12 of N-P-K, on 03/14/2015.

\subsection{Evaluations}

The evaluations of control efficiency sourgrass by the treatments applied in the burndown were carried out at 7, 14, 21 and 35 days after burndown (DAB). For post-emergent application, evaluations were performed at 7, 14, 21, 28, 35 and 55 days after application (DAA). The notes were made about the control percentage of sourgrass, on a scale from 0 (zero) absence of control to 100 (one hundred), which indicates the death of the plants (SBCPD, 1995).

Samples of soil and rhizosphere of sourgrass and maize, for nematological analysis, were 
done monthly in March (1 day before burndown), April (37 DAB), May (30 DAA) and June 2015 (60 DAA). The samples were composed of three sub-samples, taken from 0 to $20 \mathrm{~cm}$ deep and homogenized. After sampling, the samples were packed in plastic packages, duly identified, and kept in a refrigerated environment $\left( \pm 8{ }^{\circ} \mathrm{C}\right)$, until the time of analysis.

Before the nematode extractions, the samples were standardized in portions of 10 grams of roots, which were cut into $2 \mathrm{~cm}$ pieces and subjected to extraction (Coolen and D'Herde, 1972). For the extraction of nematodes from the soil, the sample content was homogenized, using $100 \mathrm{~cm}^{3}$ of soil for extraction, according to the centrifugal fluctuation method in sucrose solution (Jenkins, 1964). The samples obtained were evaluated using a Peters chamber, under an optical microscope. To estimate the reproduction of the nematode Pratylenchus spp. the reproduction factor (RF) was calculated in the periods between the months of May / April and June / April, determined by the ratio between the final population (FP) and the initial population (IP) (Oostenbrink, 1966).

At the end of the crop cycle, agronomic characteristics were evaluated: plant height $(\mathrm{cm})$, number of grain rows per ear, number of grains per row, 100 grain mass $(\mathrm{g})$ and yield $(\mathrm{kg}$ $\left.\mathrm{ha}^{-1}\right)$.

\subsection{Statistic Analysis}

The assumptions of normality were attended by the data related to the management of the weed (sourgrass) and of the maize culture and were subjected to the variance analysis. When significant, the treatment averages were compared by the Tukey test with 5\% of probability, using the Sisvar 5.3 ${ }^{\mathrm{TM}}$ statistical software (Ferreira, 2011). Regarding the nematode Pratylenchus spp. data, they did not attend the assumption of normality. Therefore, the Friedman test with $5 \%$ of probability was applied, based on the Qui-square distribution (Friedman, 1937; PimenteL-Gomes, 2009), using the Assistat 7.7 ${ }^{\mathrm{TM}}$ statistical software.

\section{Results and Discussion}

In the evaluation of sourgrass control at $7 \mathrm{DAB}$, the lowest levels of efficiency were found for the herbicide glyphosate used alone $(6.8 \%)$, followed by the association of glyphosate + fenoxaprop-p-ethyl + 2.4-D which, despite higher than glyphosate, it was still considered unsatisfactory (70\%) (Table 2). For glyphosate + clethodim + 2,4-D and glyphosate + fenoxaprop-p-ethyl, satisfactory levels of control (82.2\% and 83.6\%) were found, according to SBCPD (1995) criteria, but significantly lower than glyphosate + clethodim, which reached excellent efficiency $(92.2 \%)$. At $14 \mathrm{DAB}$, the associations of glyphosate + clethodim and glyphosate + fenoxaprop-p-ethyl stood out for the levels of sourgrass control, but evidenced the initial negative influence of 2.4-D when associated with these treatments. 
Table 2. Control $(\%)$ of sourgrass submitted to the burndown management in off-season maize crop at 7, 14, 21 and 35 days after burndown (DAB)

\begin{tabular}{|c|c|c|c|c|c|}
\hline Burndown & $\begin{array}{c}\text { Doses } \\
\text { (g ai or ae } \\
\left.\mathrm{ha}^{-1}\right)^{1 / 1}\end{array}$ & $\begin{array}{c}\text { 7DAB } \\
\%\end{array}$ & $\begin{array}{c}\text { 14DAB } \\
\%\end{array}$ & $\begin{array}{c}21 \mathrm{DAB} \\
\%\end{array}$ & $\begin{array}{c}35 \mathrm{DAB} \\
\%\end{array}$ \\
\hline Weeded control & - & $100.0 \mathrm{a}$ & $100.0 \mathrm{a}$ & $100.0 \mathrm{a}$ & $100.0 \mathrm{a}$ \\
\hline Control without hoeing & - & $0.0 \mathrm{e}$ & $0.0 \mathrm{~d}$ & $0.0 \mathrm{~d}$ & $0.0 \mathrm{~d}$ \\
\hline Glyphosate $^{/ 2}$ & 1440 & $6.8 \mathrm{~d}$ & $8.6 \mathrm{c}$ & $10.8 \mathrm{c}$ & $11.6 \mathrm{c}$ \\
\hline $\mathrm{GLF}^{/ 2}+$ clethodim $^{13 / 6}$ & $1440+192$ & $92.2 \mathrm{a}$ & $99.4 \mathrm{a}$ & $100.0 \mathrm{a}$ & $100.0 \mathrm{a}$ \\
\hline $\mathrm{GLF}^{\prime 2}+$ fenoxaprop-p-ethyl ${ }^{/ 4}$ & $1440+220$ & $83.6 \mathrm{~b}$ & $96.2 \mathrm{a}$ & $96.4 \mathrm{a}$ & $92.0 \mathrm{a}$ \\
\hline $\mathrm{GLF}^{/ 2}+$ clethodim $^{/ 3}+2.4-\mathrm{D}^{15 / 6}$ & $1440+192+670$ & $82.2 \mathrm{~b}$ & $91.8 \mathrm{a}$ & $96.0 \mathrm{a}$ & $95.8 \mathrm{a}$ \\
\hline $\mathrm{GLF}^{/ 2}+$ fenoxaprop $^{/ 4}+2.4-\mathrm{D}^{/ 5}$ & $1440+220+670$ & $70.0 \mathrm{c}$ & $84.0 \mathrm{~b}$ & $86.2 \mathrm{~b}$ & $84.2 \mathrm{~b}$ \\
\hline Calculated F & - & $620 *$ & $634 *$ & $1.549^{*}$ & $1.676^{*}$ \\
\hline Coefficient of variation (\%) & - & 4.67 & 4.59 & 2.86 & 2.71 \\
\hline $\operatorname{MSD}(5 \%)$ & - & 0.67 & 0.70 & 0.44 & 0.42 \\
\hline
\end{tabular}

${ }^{11} \mathrm{ai}=$ active ingredient; ae $=$ acid equivalent; ${ }^{/ 2}$ Roundup Original ${ }^{\mathrm{TM}}\left(360 \mathrm{~g} \mathrm{~L}^{-1}\right) ;{ }^{1 / 3} \mathrm{Select} \mathrm{TM}^{\mathrm{TM}}$ $\left(240 \mathrm{~g} \mathrm{~L}^{-1}\right) ;{ }^{/ 4}$ Podium EWTM $\left(110 \mathrm{~g} \mathrm{~L}^{-1}\right) ;{ }^{15} \mathrm{DMA} 806 \mathrm{BR}^{\mathrm{TM}}\left(670 \mathrm{~g} \mathrm{~L}^{-1}\right) ;{ }^{16}$ addition of $0.5 \% \mathrm{v} / \mathrm{v}$ of Lanzar ${ }^{\mathrm{TM}}$ adjuvant. *Averages in the same column followed by the same letter do not differ by Tukey's test $(\mathrm{p} \leq 0.05)$. MSD = minimal significant difference.

Between 21 and $35 \mathrm{DAB}$, the control of sourgrass with the associations of glyphosate + clethodim, glyphosate + fenoxaprop-p-ethyl and glyphosate + clethodim + 2.4-D maintained the levels of efficiency excellent and close to those observed at 14 DAB, surpassing significantly the glyphosate + fenoxaprop-p-ethyl $+2.4-\mathrm{D}$ treatment (Table 2). These results corroborate with Grigolli (2014) and Fornarolli et al. (2015), who highlighted the possibility of antagonistic effects at varying levels in the control of sourgrass when using 2.4-D associations with ACCase enzyme inhibiting herbicides, with clethodim being the least affected. Marcon (2015) also found a significant reduction in the control and deposition of the spray mixture in sourgrass for associations of glyphosate + ACCase + 2.4-D, and among the graminicides, clethodim was the one that presented the least interference when mixed with 2.4-D. 
The antagonistic effect of 2.4-D on the action of ACCase-inhibiting graminicides has been related to a reduction in translocation and an increase in the metabolism of herbicides in the aryloxyphenoxypropionic group (Roman et al., 2007; Trezzi et al., 2007). However, the information that considers the negative action of 2.4-D, when associated with glyphosate and ACCase inhibitors in the same tank mixture, has been questioned, both in the control of voluntary plants, as in the case of $\mathrm{RR}^{\circledR}$ maize, as well as other weed species resistant and/or tolerant to herbicides (Maciel et al., 2013).

In addition, even for the burndown management condition, it is important to consider that the application of glyphosate alone did not effectively control sourgrass until 35 DAB (11.6\%), which shows that these are biotypes with a high level of resistance to glyphosate, with the efficiency for this plant population much lower than the values observed by Correia and Durigan (2009) at 28 DAB (41.2\%), Melo et al. (2012) at 35 DAB (65.0\%), Gemelli et al. (2013a) at $30 \mathrm{DAB}(30.0 \%)$ and Barroso et al. (2014) at $28 \mathrm{DAB}(47.7 \%)$.

Regarding the continuity of sourgrass control through the application in post-emergence of the off-season maize, it was observed that the association of glyphosate + atrazine did not provide satisfactory control until 55 DAA, presenting maximum efficiency of $26.5 \%$ at 35 DAA (Table 3), since this treatment came from plants that were not satisfactorily controlled with glyphosate in the burndown management (Table 2). However, the application of glyphosate + atrazine + tembotrione in post-emergence of RR off-season maize maintained excellent levels of sourgrass control from 7 DAA ( $\geq 96 \%$ ), when pre-planting burndown was carried out with associations of glyphosate + clethodim, glyphosate + fenoxaprop-p-ethyl and glyphosate + clethodim $+2.4-\mathrm{D}$, and from 14 DAA $(\geq 92.0 \%)$, using glyphosate + fenoxaprop-p-ethyl $+2.4-\mathrm{D}$ (Table 2). It is noteworthy that the post-emergence application of the associations of glyphosate + atrazine and glyphosate + atrazine + tembotrione did not cause visual aspects of phytotoxic injuries in the shoot of the hybrid maize $2 \mathrm{~B} 712$ PowerCore ${ }^{\mathrm{TM}}$. In terms of selectivity, other studies also did not mention phytotoxic effects for associations with the same herbicides, when used in conventional maize or $\mathrm{RR}^{\circledR}$ (Zagonel et al., 2010; Gemelli et al., 2013b; Ulguim et al., 2013; Vieira Jr et al., 2015). 


\section{Ml Macrothink}

Journal of Agricultural Studies

ISSN 2166-0379

2020, Vol. 8, No. 2

Table 3. Control (\%) of sourgrass submitted to application in post-emergence of off-season maize crop at 7, 14, 21, 28, 35 and 55 days after application (DAA)

Post-emergence

Doses 7DAA 14DAA 21DAA 28DAA 35DAA 55DAA

$\begin{array}{lllllll}\left.\text { g ai or ae } \mathrm{ha}^{-1}\right)^{\prime} & \% & \% & \% & \% & \% & \%\end{array}$

Weeded control

Control without hoeing

Glyphosate $^{2}+$ atrazine $^{13}$

$960+1000$

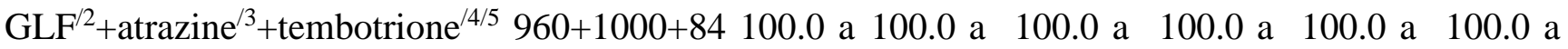

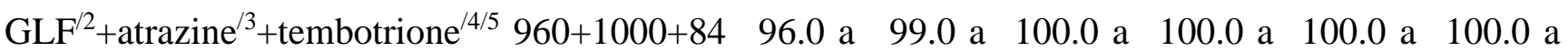
$\mathrm{GLF}^{/ 2}+$ atrazine $^{/ 3}+$ tembotrione $^{/ 4 / 5} 960+1000+84 \quad 96.0$ a 98.0 a 100.0 a 100.0 a 100.0 a 100.0 a

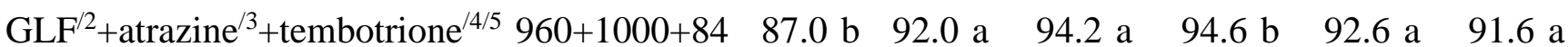

\section{$2.333 * 1.566 *$}

2.18

0.34

0.42

2.12

0.94

2.11

2.12

$\operatorname{MSD}(5 \%)$

$\quad 0.34$

${ }^{/ 1} \mathrm{ai}=$ active ingredient; ae $=$ acid equivalent; ${ }^{12}$ Roundup Transorb $\mathrm{R}\left(480 \mathrm{~g} \mathrm{~L}^{-1}\right) ;{ }^{13}$ Primóleo (400 $\left.\mathrm{g} \mathrm{L}^{-1}\right) ;{ }^{14}$ Soberan $\left(420 \mathrm{~g} \mathrm{~L}^{-1}\right) ;{ }^{15}$ addition of $0.5 \% \mathrm{v} / \mathrm{v}$ of adjuvant Aureo ${ }^{\mathrm{TM}}$. *Averages in the same column followed by the same letter do not differ by Tukey's test $(\mathrm{p} \leq 0.05)$. MSD = minimal significant difference.

No significant differences were found for Pratylenchus spp. $10 \mathrm{~g}^{-1}$ of sourgrass root, by Friedman's non-parametric test, among the treatments studied in the burndown management and post-emergence, in the analysis carried out in March (previous), April, May and June (Table 4). For these evaluations, a calculated fr of 1.72, 3.52, 9.11 and 11.85 was established, respectively. The results of the previous evaluation in March indicated a tendency towards balance in the abundance of the population of Pratylenchus spp. between treatments. However, in April, despite the fact that no significant difference was detected between treatments, it was possible to observe a trend towards an average reduction in the abundance of the nematode in relation to the evaluation in the previous month. This estimate of a reduction in the population of Pratylenchus spp. in April, when sourgrass was under the effects of burndown management, was characterized as medium intensity for the control 
without weeding (53.6\%) and glyphosate $(34.1 \%)$ and more expressive for associations of glyphosate + clethodim (76.1\%); glyphosate + clethodim + 2.4-D (76.5\%); glyphosate + fenoxaprop-p-ethyl (67.2\%) and glyphosate + fenoxaprop-p-ethyl + 2.4-D (77.8\%) (Table 4). The absence of statistical difference can be attributed to the high population variation that the nematodes present in the field, which makes the analysis difficult.

Table 4. Average abundance of Pratylenchus spp. recovered in 10 grams of plant roots of sourgrass plants submitted to burndown and post-emergence management of the off-season maize crop

Pratylenchus spp. $10 \mathrm{~g}^{-1}$ root of sourgrass

Burndown
Post-emergence

\section{March}

(previou

April May June

s)

\begin{tabular}{|c|c|c|c|c|c|}
\hline Weeded control & Weeded control & - & - & & - \\
\hline Control without hoeing & Control without hoeing & 1364 & 633 & 1466 & 338 \\
\hline Glyphosate $^{2}$ & Glyphosate $^{1 / 3}+$ atrazine $^{7}$ & 949 & 625 & 902 & 580 \\
\hline $\mathrm{GLF}^{/ 2}+$ clethodim $^{/ 4 / 9}$ & $\begin{array}{l}\mathrm{GLF}^{3}+\text { atrazine }^{7}+\text { tembotrio } \\
\mathrm{ne}^{/ 8 / 10}\end{array}$ & 1089 & 260 & 2342 & 0 \\
\hline $\begin{array}{l}\mathrm{GLF}^{/ 2}+\text { fenoxapro-p-eth } \\
\mathrm{yl}^{15}\end{array}$ & $\begin{array}{l}\mathrm{GLF}^{3}+\text { atrazine } \\
\mathrm{ne}^{7 / 10}+\text { tembotrio }^{/ 8}\end{array}$ & 1132 & 266 & 2057 & 0 \\
\hline $\begin{array}{l}\mathrm{GLF}^{/ 2}+\text { clethodim }^{14}+2.4- \\
\mathrm{D}^{/ 6 / 9}\end{array}$ & $\begin{array}{l}\mathrm{GLF}^{3}+\text { atrazine }^{7}+\text { tembotrio } \\
\mathrm{ne}^{/ 8 / 10}\end{array}$ & 710 & 238 & 3418 & 0 \\
\hline $\begin{array}{l}\mathrm{GLF}^{/ 2}+\text { fenoxaprop }^{15}+2 \\
4-\mathrm{D}^{/ 6}\end{array}$ & $\begin{array}{l}\mathrm{GLF}^{3}+\text { atrazine }^{7}+\text { tembotrio } \\
\mathrm{ne}^{/ 8 / 10}\end{array}$ & 1397 & 310 & 1316 & 0 \\
\hline $\begin{array}{l}\text { Calculated Friedman } \\
\text { test }\end{array}$ & & $1.72^{\mathrm{NS}}$ & $3.52^{\mathrm{NS}}$ & $9.11^{\mathrm{NS}}$ & $11.85^{\mathrm{NS}}$ \\
\hline Critical difference $(5 \%)$ & & 3.37 & 3.37 & 3.37 & 3.37 \\
\hline
\end{tabular}

${ }^{12}$ Roundup Original ${ }^{\mathrm{TM}}\left(360 \mathrm{~g} \mathrm{~L}^{-1}\right) ;{ }^{13}$ Roundup Transorb R RM $\left(480 \mathrm{~g} \mathrm{~L}^{-1}\right) ;{ }^{1 / 4} \operatorname{Select}{ }^{\mathrm{TM}}\left(240 \mathrm{~g} \mathrm{~L}^{-1}\right)$; ${ }^{15}$ Podium EW ${ }^{\mathrm{TM}}\left(110 \mathrm{~g} \mathrm{~L}^{-1}\right)$; ${ }^{16} \mathrm{DMA} 806 \mathrm{BR}^{\mathrm{TM}}\left(670 \mathrm{~g} \mathrm{~L}^{-1}\right) ;{ }^{17} \operatorname{Primoleo}^{\mathrm{TM}}\left(400 \mathrm{~g} \mathrm{~L}^{-1}\right)$; ${ }^{18}$ Soberan $^{\mathrm{TM}}\left(420 \mathrm{~g} \mathrm{~L}^{-1}\right)$; addition of $0.5 \% \mathrm{v} / \mathrm{v}$ of ${ }^{19} \mathrm{Lanzar}^{\mathrm{TM}}$ and ${ }^{10} \mathrm{Aureo}^{\mathrm{TM}}$ adjuvants. 
*=significant; ${ }^{\mathrm{NS}}=$ not significant.

Conversely, in May, there was a significant increase in the population of Pratylenchus spp. in the roots of sourgrass, mainly in relation to the evaluation in April and, with some exceptions, in relation to March (Table 4). In general, the increase in population was more evident for treatments with associations of post-emergence management herbicides, except for the application of glyphosate + fenoxaprop-p-ethyl +2.4 -D/glyphosate + atrazine + tembotrione . It should be noted that, in May, the sourgrass plants were under the effects of burndown management and post-emergence treatments. However, in June, densities of Pratylenchus spp. were found in the sourgrass roots of the treatments control without weeding and glyphosate, certainly due to the presence of live plants in these plots (Table 4). For the other treatments, possibly the advanced stage of decomposition of the root system of sourgrass and the reduction in rainfall, may have contributed to a reduction in the viable roots of the host plant.

Previous studies, in field and greenhouse conditions, also did not show effects of glyphosate or haloxyfop (ACCase) herbicides on the nematode density of this genus in soybean roots (Macedo, 2012). On the other hand, the herbicides pendimethalin, atrazine and acetochlor, applied in pre-emergence, and 2.4-D, dicamba, dicamba + atrazine and nicosulfuron, applied in post-emergence of maize, in an area infested with Johnson grass (Sorghum halepense), sunflower (Helianthus annuus), purslane (Portulaca oleracea) and sweet clover (Melilotus indicus), promoted the reduction of Pratylenchus spp. on the soil, in the evaluations performed 60 days after application (Castro-Carvajal et al., 2015). Similarly, paraquat and carfentrazone-ethyl reduced the population of P. brachyurus in soybean (Riboldi et al., 2013). The results obtained in other pathosystems involving weeds and nematodes are also variable depending on the active ingredient and time of application, however, in general, herbicides do not affect or reduce nematodes (Levene, 1995; Nelson et al., 2006; Werle et al., 2013).

In this study, a gradual decline in the population of Pratylenchus spp. in the roots of sourgrass over time (sampling) was expected, especially in treatments with the application of herbicide combinations consisting of ACCase inhibitors, for the efficient control of sourgrass, in addition to the gradual drop in temperature averages during the crop cycle (fall and winter). However, this trend was discontinued by the increase in the population density of the nematode in the roots of sourgrass in May, regardless of the association of herbicides used. Such an effect may be associated with changes in environmental conditions, especially in rainfall accumulated in May, $102 \mathrm{~mm}$ higher than the previous evaluation (Figure 1). It is known that the population density of nematode species has a positive correlation with rainfall, as already observed for Pratylenchus penetrans in maize crops (Jordaan et al., 1989; McDonald and Van Den Berg, 1993). Added to this, there is the natural senescence of plants, reducing the number of viable roots.

The Friedman test, performed on the total of Pratylenchus spp. recovered in the joint samples of roots $(10 \mathrm{~g})$ and soil $\left(100 \mathrm{~cm}^{3}\right)$ of sourgrass rhizosphere, did not indicate significant differences between the management systems in the samples of March, April and May. However, in June there was a significant difference between the systems with the herbicide associations, with glyphosate + clethodim $+2.4-\mathrm{D} /$ glyphosate + atrazine + tembotrione 
standing out for the lower abundance of the population of Pratylenchus spp. (Table 5). This result shows that the efficient management of the weed can positively interfere in the nematode control, as already reported when comparing the effect of ghyphosate with paraquat and carfentrazone-ethyl (Riboldi et al., 2013).

Table 5. Average abundance of Pratylenchus spp. total, recovered from $10 \mathrm{~g}$ roots and 100 $\mathrm{cm}^{3}$ soil from the rhizosphere of sourgrass plants submitted to burndown and post-emergence management of the off-season maize crop

Total number of Pratylenchus spp.

(root+soil)

Burndown Post-emergence

March
(previous)

Weeded control Weeded control

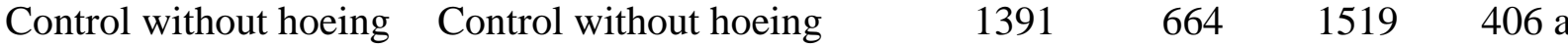

$\begin{array}{llllll}\text { Glyphosate }^{/ 2} & \text { Glyphosate }^{13}+\text { atrazine }^{7} & 994 & 651 & 931 & 603 \mathrm{ab}\end{array}$

$\mathrm{GLF}^{/ 2}+$ clethodim $^{/ 4 / 9} \quad \begin{aligned} & \mathrm{GLF}^{/ 3}+\text { atrazine }^{/ 7}+\text { tembotrio } \\ & \mathrm{ne}^{1 / 10}\end{aligned} \quad \begin{array}{llll}1116 & 260 & 2385 & 42 \mathrm{ab}\end{array}$

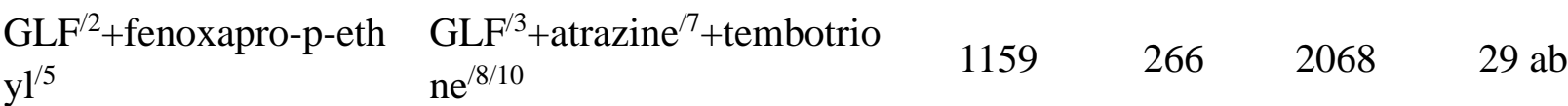

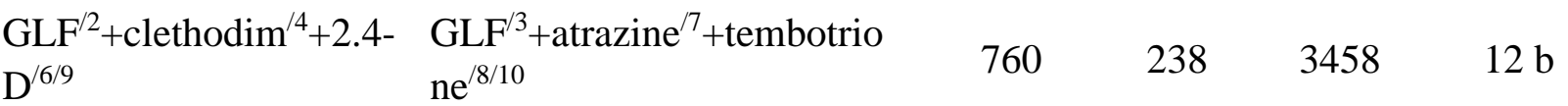

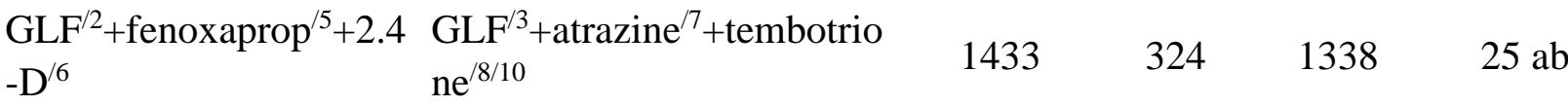

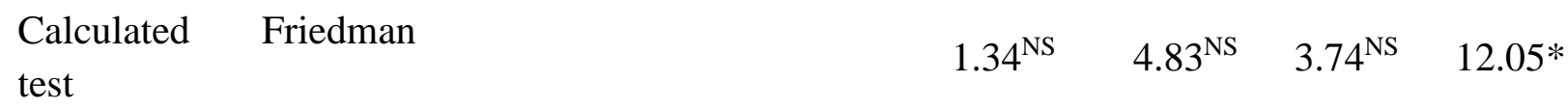

Critical difference $(5 \%)$

$\begin{array}{lll}3.37 & 3.37 & 3.37\end{array}$

${ }^{12}$ Roundup Original ${ }^{\mathrm{TM}}\left(360 \mathrm{~g} \mathrm{~L}^{-1}\right) ;{ }^{13}$ Roundup Transorb R ${ }^{\mathrm{TM}}\left(480 \mathrm{~g} \mathrm{~L}^{-1}\right) ;{ }^{14} \operatorname{Select}^{\mathrm{TM}}\left(240 \mathrm{~g} \mathrm{~L}^{-1}\right)$; ${ }^{15}$ Podium EW ${ }^{\mathrm{TM}}$ (110 $\left.\mathrm{g} \mathrm{L}^{-1}\right)$; ${ }^{16} \mathrm{DMA} 806 \mathrm{BR}^{\mathrm{TM}}\left(670 \mathrm{~g} \mathrm{~L}^{-1}\right) ;{ }^{17} \operatorname{Primoleo}^{\mathrm{TM}}\left(400 \mathrm{~g} \mathrm{~L}^{-1}\right)$; ${ }^{18}$ Soberan $^{\mathrm{TM}}\left(420 \mathrm{~g} \mathrm{~L}^{-1}\right)$; addition of $0.5 \% \mathrm{v} / \mathrm{v}$ of ${ }^{19} \mathrm{Lanzar}^{\mathrm{TM}}$ and ${ }^{10} \mathrm{Aureo}^{\mathrm{TM}}$ adjuvants. $*=$ significant; ${ }^{\mathrm{NS}}=$ not significant.

In the April evaluation, although there were no significant differences by the Friedman test, 
an average increase in the population of Pratylenchus spp. in maize roots was observed for herbicide management systems compared to weeding and no weeding controls, in the order of $55.4 \%$ and $4.8 \%$, respectively (Table 6). This result highlights the importance of the sourgrass as a host of Pratylenchus spp., even in plants submitted to the management systems with the studied herbicide associations and corroborates previous research that showed the sourgrass susceptibility to the lesion nematode (Bellé et al., 2015; Matias et al., 2018), which may be similar to that observed for maize (Matias et al., 2018). The nematode population found in the maize rhizosphere was very low and uniform, with no difference between treatments or contributing significantly to the total population (data not shown).

Table 6. Abundance averages of Pratylenchus spp., recovered in $10 \mathrm{~g}$ of maize roots submitted to burndown and post-emergence management of the off-season maize crop

\begin{tabular}{|c|c|c|c|c|}
\hline \multirow{2}{*}{ Burndown } & \multirow{2}{*}{ Post-emergence } & \multicolumn{3}{|c|}{ Pratylenchus spp. $10 \mathrm{~g}^{-1}$ root of maize } \\
\hline & & April & May & June \\
\hline Weeded control & Weeded control & 645 & 1924 & 0 \\
\hline Control without hoeing & Control without hoeing & 1373 & 1727 & 0 \\
\hline Glyphosate $^{\prime 2}$ & Glyphosate $^{1 / 3}+$ atrazine $^{7}$ & 1671 & 1800 & 0 \\
\hline $\mathrm{GLF}^{/ 2}+$ clethodim $^{/ 4 / 9}$ & $\mathrm{GLF}^{/ 3}+$ atrazine $^{/ 7}+$ tembotrione $\mathrm{e}^{/ 8 / 10}$ & 1354 & 2378 & 366 \\
\hline $\mathrm{GLF}^{\prime 2}+$ fenoxapro-p-ethyl $\mathrm{l}^{15}$ & $\mathrm{GLF}^{/ 3}+$ atrazine $^{17}+$ tembotrione $\mathrm{e}^{/ 8 / 10}$ & 1855 & 1933 & 998 \\
\hline $\mathrm{GLF}^{/ 2}+$ clethodim $^{/ 4}+2.4-\mathrm{D}^{16 / 9}$ & $\mathrm{GLF}^{/ 3}+$ atrazine $^{/ 7}+$ tembotrione $\mathrm{e}^{/ 8 / 10}$ & 1270 & 1691 & 387 \\
\hline $\mathrm{GLF}^{2}+$ fenoxaprop $^{15}+2.4-\mathrm{D}^{16}$ & $\mathrm{GLF}^{/ 3}+$ atrazine $^{17}+$ tembotrione $^{18 / 10}$ & 1125 & 1952 & 1338 \\
\hline Calculated Friedman test & & $4.97^{\mathrm{NS}}$ & $5.22^{\mathrm{NS}}$ & $9.91^{\mathrm{NS}}$ \\
\hline Critical difference (5\%) & & 4.03 & 4.03 & 4.03 \\
\hline
\end{tabular}

${ }^{12}$ Roundup Original ${ }^{\mathrm{TM}}\left(360 \mathrm{~g} \mathrm{~L}^{-1}\right) ;{ }^{13}$ Roundup Transorb RTM $\left(480 \mathrm{~g} \mathrm{~L}^{-1}\right) ;{ }^{14} \operatorname{Select}^{\mathrm{TM}}\left(240 \mathrm{~g} \mathrm{~L}^{-1}\right)$; ${ }^{15}$ Podium EW EW (110 g L $\left.{ }^{-1}\right)$; ${ }^{16}$ DMA 806 BR $^{\mathrm{TM}}\left(670 \mathrm{~g} \mathrm{~L}^{-1}\right)$; ${ }^{17} \operatorname{Primoleo}^{\mathrm{TM}}\left(400 \mathrm{~g} \mathrm{~L}^{-1}\right)$; ${ }^{18}$ Soberan $^{\mathrm{TM}}\left(420 \mathrm{~g} \mathrm{~L}^{-1}\right)$; addition of $0.5 \% \mathrm{v} / \mathrm{v}$ of ${ }^{19} \mathrm{Lanzar}^{\mathrm{TM}}$ and ${ }^{110} \mathrm{Aureo}^{\mathrm{TM}}$ adjuvants. *=significant; ${ }^{\mathrm{NS}}=$ not significant.

The reproduction factor averages of Pratylenchus spp. in the periods of May/April and June/April were 6.50 and 0.24, respectively (Table 7). Therefore, under the conditions studied, the nematode population multiplied more in the first evaluation interval, since the environmental conditions and the host's root system were becoming inadequate throughout 
the experimental period, as previously discussed. Still in the May/April period, it was observed that, with the exception of the application of glyphosate, all other management systems had increases in the reproduction factors of Pratylenchus spp., varying from 0.8 to 5.2 times higher than the control without weeding (Table 7). This result differs from other reports in the literature, in which herbicides do not affect or reduce lesion nematodes (Jordaan and Waele, 1988; Castro-Carvajal et al., 2015) and points to the need for further research to understand whether herbicides can, somehow, positively influence the nematode reproduction in sourgrass, even if temporarily. In the period of June/April, the RF was very low for all treatments, for reasons previously discussed.

Table 7. Reproduction factor (RF) of Pratylenchus spp. in sourgrass and maize plants, submitted to burndown and post-emergence management, in evaluations between the periods of May/April and June/April

\begin{tabular}{|c|c|c|c|c|c|}
\hline \multirow{2}{*}{ Burndown } & \multirow{2}{*}{ Post-emergence } & \multirow{2}{*}{$\begin{array}{c}\text { Sourgrass } \\
\text { RF May/ }\end{array}$} & \multirow{2}{*}{$\begin{array}{l}\text { Maize } \\
\text { April }\end{array}$} & \multirow{2}{*}{$\begin{array}{c}\text { Sourgrass } \\
\text { RF June/ }\end{array}$} & \multirow{2}{*}{$\begin{array}{l}\text { Maize } \\
\text { April }\end{array}$} \\
\hline & & & & & \\
\hline Weeded control & Weeded control & - & 2.98 & - & 0.00 \\
\hline Control without hoeing & Control without hoeing & 2.31 & 1.26 & 0.53 & 0.00 \\
\hline Glyphosate $^{12}$ & Glyphosate $^{1 / 3}+$ atrazine $^{7}$ & 1.44 & 1.08 & 0.93 & 0.00 \\
\hline $\mathrm{GLF}^{/ 2}+$ clethodim $^{1 / 9}$ & 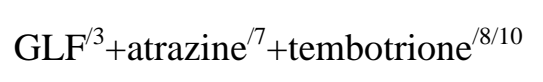 & 8.98 & 1.76 & 0.00 & 0.27 \\
\hline $\mathrm{GLF}^{/ 2}+$ fenoxapro-p-ethyl ${ }^{15}$ & $\mathrm{GLF}^{/ 3}+$ atrazine $^{/ 7}+$ tembotrione $^{/ 8 / 10}$ & 7.71 & 1.04 & 0.00 & 0.54 \\
\hline $\mathrm{GLF}^{2}+$ clethodim $^{14}+2.4-\mathrm{D}^{16 / 9}$ & $\mathrm{GLF}^{/ 3}+$ atrazine $^{17}+$ tembotrione $^{18 / 10}$ & 14.32 & 1.33 & 0.00 & 0.31 \\
\hline $\mathrm{GLF}^{2}+$ fenoxaprop $^{15}+2.4-\mathrm{D}^{16}$ & $\mathrm{GLF}^{/ 3}+$ atrazine $^{/ 7}+$ tembotrione $^{18 / 10}$ & 4.24 & 1.74 & 0.00 & 1.19 \\
\hline Medias & & 6.50 & 1.60 & 0.24 & 0.33 \\
\hline
\end{tabular}

${ }^{12}$ Roundup Original ${ }^{\mathrm{TM}}\left(360 \mathrm{~g} \mathrm{~L}^{-1}\right) ;{ }^{13}$ Roundup Transorb RTM $\left(480 \mathrm{~g} \mathrm{~L}^{-1}\right) ;{ }^{1 / 4} \operatorname{Select}^{\mathrm{TM}}\left(240 \mathrm{~g} \mathrm{~L}^{-1}\right)$; ${ }^{15}$ Podium EW ${ }^{\mathrm{TM}}$ (110 g L $\left.{ }^{-1}\right)$; ${ }^{16} \mathrm{DMA} 806 \mathrm{BR}^{\mathrm{TM}}$ (670 $\left.\mathrm{g} \mathrm{L}^{-1}\right)$; ${ }^{17} \operatorname{Primoleo}^{\mathrm{TM}}$ (400 $\left.\mathrm{g} \mathrm{L}^{-1}\right)$; ${ }^{18}$ Soberan $^{\mathrm{TM}}\left(420 \mathrm{~g} \mathrm{~L}^{-1}\right)$; addition of $0.5 \% \mathrm{v} / \mathrm{v}$ of ${ }^{/ 9}$ Lanzar $^{\mathrm{TM}}$ and ${ }^{110} \mathrm{Aureo}^{\mathrm{TM}}$ adjuvants.

The analysis of variance did not identify significant differences between treatments for agronomic characteristics, 100 grain mass and number of rows per ear (Table 8). However, the lowest observed averages of these variables occurred for the control without weeding and the glyphosate/glyphosate + atrazine management system, which constitutes the presence of the weed competition between sourgrass and the crop, since the control was inefficient in those treatments. This result was also confirmed for the number of grains per row, with a 
significant reduction only for the same treatments, confirming the interference of weed competition for this characteristic (Table 8).

Table 8. Height, number of grain rows per ear (NRE), number of grains per row (NGR), 100 grain mass (M100) and yield of the off-season maize, submitted to burndown and post-emergence management of the sourgrass in the maize crop

\begin{tabular}{|c|c|c|c|c|c|c|}
\hline Burndown & Post-emergence & $\begin{array}{l}\text { Height } \\
\text { (m) }\end{array}$ & NRE & NGR & $\begin{array}{l}\text { M100 } \\
\text { (g) }\end{array}$ & $\begin{array}{c}\text { Yield } \\
\left(\mathrm{kg} \mathrm{ha}^{-1}\right)\end{array}$ \\
\hline Weeded control & Weeded control & $2.32 \mathrm{a}$ & 18 & $37 \mathrm{a}$ & 37 & $11553 \mathrm{a}$ \\
\hline Control without hoeing & Control without hoeing & $1.42 \mathrm{c}$ & 15 & $20 \mathrm{~b}$ & 34 & $3557 \mathrm{c}$ \\
\hline Glyphosate $^{2}$ & Glyphosate $^{1 / 3}+$ atrazine $^{17}$ & $1.45 \mathrm{c}$ & 16 & $23 \mathrm{~b}$ & 35 & $3629 \mathrm{c}$ \\
\hline $\mathrm{GLF}^{/ 2}+$ clethodim $^{/ 4 / 9}$ & $\begin{array}{l}\mathrm{GLF}^{/ 3}+\text { atrazine }^{/ 7}+\text { tembotrio } \\
\mathrm{ne}^{/ 8 / 10}\end{array}$ & $2.25 \mathrm{ab}$ & 18 & $35 \mathrm{a}$ & 36 & $10782 \mathrm{a}$ \\
\hline $\begin{array}{l}\mathrm{GLF}^{/ 2}+\text { fenoxapro-p-eth } \\
\mathrm{yl}^{1 / 5}\end{array}$ & $\begin{array}{l}\mathrm{GLF}^{/ 3}+\text { atrazine }^{/ 7}+\text { tembotrio } \\
\mathrm{ne}^{/ 8 / 10}\end{array}$ & $2.29 \mathrm{ab}$ & 18 & $34 \mathrm{a}$ & 36 & $\begin{array}{l}9764 \\
\mathrm{ab}\end{array}$ \\
\hline $\begin{array}{l}\mathrm{GLF}^{/ 2}+\text { clethodim }^{/ 4}+2.4 \\
-\mathrm{D}^{/ 6 / 9}\end{array}$ & $\begin{array}{l}\mathrm{GLF}^{/ 3}+\text { atrazine }^{/ 7}+\text { tembotrio } \\
\mathrm{ne}^{/ 8 / 10}\end{array}$ & $2.31 \mathrm{a}$ & 17 & $36 \mathrm{a}$ & 38 & $11508 \mathrm{a}$ \\
\hline $\begin{array}{l}\mathrm{GLF}^{/ 2}+\text { fenoxaprop }^{15}+2 . \\
4-\mathrm{D}^{/ 6}\end{array}$ & $\begin{array}{l}\mathrm{GLF}^{/ 3}+\text { atrazine }^{/ 7}+\text { tembotrio } \\
\mathrm{ne}^{/ 8 / 10}\end{array}$ & $2.11 \mathrm{~b}$ & 16 & $36 \mathrm{a}$ & 36 & $8380 \mathrm{~b}$ \\
\hline Calculated F & & $107.9 *$ & $1.0^{\mathrm{NS}}$ & $51.0 *$ & $2.0^{\mathrm{NS}}$ & $29.6 *$ \\
\hline $\begin{array}{l}\text { Coefficient } \\
\text { variation }(\%)\end{array}$ & & 1.50 & 4.20 & 2.97 & 3.00 & 9.72 \\
\hline $\operatorname{MSD}(5 \%)$ & & 0.05 & 0.34 & 0.34 & 0.37 & 17.67 \\
\hline
\end{tabular}

${ }^{12}$ Roundup Original ${ }^{\mathrm{TM}}\left(360 \mathrm{~g} \mathrm{~L}^{-1}\right) ;{ }^{13}$ Roundup Transorb R RM $\left(480 \mathrm{~g} \mathrm{~L}^{-1}\right) ;{ }^{14} \operatorname{Select}^{\mathrm{TM}}\left(240 \mathrm{~g} \mathrm{~L}^{-1}\right)$; ${ }^{15}$ Podium EW ${ }^{\mathrm{TM}}\left(110 \mathrm{~g} \mathrm{~L}^{-1}\right)$; ${ }^{16} \mathrm{DMA} 806 \mathrm{BR}^{\mathrm{TM}}\left(670 \mathrm{~g} \mathrm{~L}^{-1}\right) ;{ }^{17} \operatorname{Primoleo}^{\mathrm{TM}}\left(400 \mathrm{~g} \mathrm{~L}^{-1}\right)$; ${ }^{18}$ Soberan $^{\mathrm{TM}}\left(420 \mathrm{~g} \mathrm{~L}^{-1}\right)$; addition of $0.5 \% \mathrm{v} / \mathrm{v}$ of ${ }^{19} \mathrm{Lanzar}^{\mathrm{TM}}$ and ${ }^{110}$ Aureo ${ }^{\mathrm{TM}}$ adjuvants. Averages in the same column followed by the same letter do not differ by Tukey's test $(\mathrm{p} \leq 0.05) . \mathrm{MSD}=$ minimal significant difference. ${ }^{*}=$ significant; ${ }^{\mathrm{NS}}=$ not significant.

For the plant height and grain yield characteristics, the greatest losses occurred for the control without weeding and the glyphosate/glyphosate + atrazine management system, in which 
average reductions of $38.4 \%$ and $68.9 \%$ were characterized, respectively, in relation to the weeding control (Table 8). The sourgrass management system with the association of glyphosate + fenoxaprop-p-ethyl $+2.4-\mathrm{D}$, followed by glyphosate + atrazine + tembotrione in post-emergence, also promoted a reduction in height and yield close to $9.0 \%$ and $27.5 \%$, respectively, in relation to the weeded control. This treatment, in spite of promoting efficient control of the sourgrass, did not reach maximum efficiency until the end of the crop cycle, thus resulting in direct losses related to weed interference in the development of the crop. In this way, the management systems of sourgrass with the associations of the herbicides glyphosate + clethodim; glyphosate + clethodim $+2.4-\mathrm{D}$ and glyphosate + fenoxaprop-p-ethyl, all followed by glyphosate + atrazine + tembotrione, did not differ significantly from the weeded control for all agronomic characteristics evaluated (Table 8).

It is important to note that despite the glyphosate + clethodim associations; glyphosate + clethodim + 2.4-D and glyphosate + fenoxaprop-p-ethyl, followed by the application of glyphosate + atrazine + tembotrione have been the best management systems in the control of glyphosate-resistant sourgrass, the results obtained do not allow to state with accuracy their contribution to reducing possible damage caused by Pratylenchus spp. in the off-season maize crop. The results showed that, for the management system situation in which the sourgrass control was not highly efficient (100\%), the crop lived with competition pressure and a larger nematode population, which resulted in reduced development and yield of the off-season maize. However, it was observed that the management system with glyphosate + clethodim $+2.4-\mathrm{D}$, followed by glyphosate + atrazine + tembotrione induced a reduction in the population of Pratylenchus spp. in sourgrass, but any management system has repeated this effect in off-season maize plants. In this context, further research is still needed to better clarify the results of the interaction between management practices and nematode dynamics both in the host plant and in the off-season maize crop.

\section{Conclusion}

It is concluded that the management system with glyphosate + clethodim + 2.4-D followed by glyphosate + atrazine + tembotrione reduced the Pratylenchus spp. population in sourgrass, but any management system repeated this effect in maize. Management systems of $D$. insularis with associations of glyphosate + clethodim; glyphosate + clethodim + 2.4-D and glyphosate + fenoxaprop-p-ethyl, all followed by glyphosate + atrazine + tembotrione, showed excellent control level of sourgrass without affecting plant height, grain and rank numbers and grain yield. Lastly, management system with used herbicides associated controlled sourgrass and may interferer on Pratylenchus spp. population.

\section{References}

Barbosa, K. A. G., Seii, A. H., Rocha, M. R., Teixeira, R. A., Santos, L. C., \& Araújo, F. G. (2014). Interação entre herbicidas e cultivares de soja sobre o nematoide de cisto Heterodera glycines. Bioscience Journal, 30(1), 154-163. Retrieved from http://www.seer.ufu.br/index.php/biosciencejournal/article/view/14387

Barroso, A. A. M., Albrecht, A. J. P., Reis, F. C., \& Filho R. V. (2014). ACCase and 
glyphosate different formulations herbicides association interactions of sourgrass control. Planta Daninha, 32(3), 619-627. https://doi.org/10.1590/S0100-83582014000300018

Bellé, C., Limat-Medina, I., Kaspary, T. E., \& Kuhn, P. R. (2015). Capacidad hospedadora de plantas adventicias a Pratylenchus brachyurus en el noroeste de Rio Grande del Sul, Brasil. Nematropica, 45(3), 144-149. https://journals.flvc.org/nematropica/article/view/86875

Castro-Carvajal, J. M., Parra-Terrazas, S., González-Acosta, A., Gonzales-Castro, A., Gerra-Liera, J. E., Caro-Macias, P. H., \& Lopez-Meza, M. (2015). Manejo de herbicidas en maíz, residualidad en la rotación con otros cultivos e impacto sobre la microbiota del suelo. Revista Científica Biológico Agropecuária Tuxpan, 3, 1002-1007.

Caviglione, J. H., Kijhl, L. R. B., Caramori, P. H., \& Giacomini, C. C. (2000). Cartas climáticas do Paraná. Versão 1.0. Londrina: IAPAR. 1 CD-ROM.

Coolen, W. A., \& D'Herde, C. J. (1972). A method for the quantitative extraction of nematodes from plant tissue. Ghent, Belgian, State of Nematology and Entomology Research Station.

Correia, N. M., \& Durigan, J. C. (2009). Manejo químico de plantas adultas de Digitaria insularis (L.) Fedde com glyphosate isolado e em mistura com chlorimuron ethyl ou quizalofop-p-tefuril em área de plantio direto. Bragantia, 68(3), 689-697. https://doi.org/10.1590/S0006-87052009000300016

Costa, N. V., Moratelli, G., Ferreira, S. D., Salvalaggio, A. C., \& Rodrigues-Costa, A. C. P. (2018). Resistance to glyphosate in populations of Digitaria insularis. Planta Daninha, 36, e018175918. https://doi.org/10.1590/S0100-83582018360100131

Dias-Arieira, C. R., Ferraz, S., \& Ribeiro, R. C. F. (2009). Reação de gramíneas forrageiras a Pratylenchus brachyurus. Nematologia Brasileira, 33(1), 90-93.

Favoreto, L., Meyer, M. C., Dias-Arieira, C. R., Machado, A. C. Z., Santiago, D. C., \& Ribeiro, N. R. (2019). Diagnose e manejo de fitonematoides na cultura da soja. Informe Agropecuário, 40, 18-29.

Fornarolli, D. A., Gazzieiro, D. L. P., Meschede, D. K., \& Rodrigues, B. N. (2015). Solução integrada. Cultivar: Grandes Culturas, 192, 8-11.

Friedman, M. (1937). The use of ranks to avoid the assumption of normality implicit in the analysis of variance. Journal of the American Statistical Association, 32(200), 675-701. JSTOR 2279372. https://doi.org/10.2307/2279372

Garcia, R. A., Li, Y., \& Rosolem, C. A. (2013). Soil organic matter and physical attributes affected by crop rotation under no-till. Soil Science Society of American Journal, 77, 1724-1731. https://doi.org/10.2136/sssaj2012.0310

Gemelli, A., Oliveira Junior, R. S., \& Constantin, J. (2013a). Estratégias para o controle de capim-amargoso (Digitaria insularis) resistente ao glyphosate, desde a dessecação de manejo até a pós-emergência da soja RR. Informe Técnico PGA-UEM, 02(2), 01-05. https://doi.org/10.7824/rbh.v12i2.201 
Gemelli, A., Oliveira Junior., R. S., Constantin, J., Braz, G. B. P., Jumes, T. M. C., Gheno, E. A. A., Rios, F. A., \& Franchini, L. H. M. (2013b). Estratégias para o controle de capim-amargoso (Digitaria insularis) resistente ao glyphosate na cultura do milho safrinha. Revista Brasileira de Herbicidas, 12(2), 162-170. https://doi.org/10.7824/rbh.v12i2.201

Gonçalves, F. M. A., Carvalho, S. P., Ramalho, M. A. P., \& Corrêa, L. A. (1999). Importância econômica das interações cultivares $\mathrm{x}$ locais e cultivares $\mathrm{x}$ anos na avaliação de milho na safrinha. Pesquisa Agropecuária Brasileira, 34(7), 1175-1181. https://doi.org/10.1590/S0100-204X1999000700009

Grigolli, J. F J. (2014). Manejo de plantas daninhas no milho safrinha. In R. Roscoe et al. (Eds.), Tecnologia e produção: milho safrinha e culturas de inverno (pp. 105-116). Maracajú: Fundação MS.

Inomoto, M. M. (2011). Resistance evaluation of 12 maize hybrids to Pratylenchus $\begin{array}{llll}\text { brachyurus. } & \text { Tropical } & \text { Plant } & \text { Pathology, }\end{array}$ https://doi.org/10.1590/S1982-56762011000500006

Inomoto, M. M., Machado, A. C. Z., \& Antedomênico, S. R. (2007). Reação de Brachiaria spp. e Panicum maximum a Pratylenchus brachyurus. Fitopatologia Brasileira, 32(4), 341-344. https://doi.org/10.1590/S0100-41582007000400009.

Inomoto, M. M., Motta, L. C. C., Machado, A. C. Z., \& Sazaki, C. S. S. (2006). Reação de dez coberturas vegetais a Pratylenchus brachyurus. Nematologia Brasileira, 30(2), 151-157.

Jenkins, W. R. (1964). A rapid centrifugal-flotation technique for separating nematodes from soil. Plant Disease Report, 48(9), 692.

Johnson, A. W., Dowler, C. C., \& Hauser, E. W. (1975). Crop rotation and herbicide effects on population densities of plant-parasitic nematodes. Journal of Nematology, 7(2), 158-168. Retrieved from https://www.ncbi.nlm.nih.gov/pmc/articles/PMC2620095/pdf/158.pdf

Jordaan, E. M., \& Waele, D. (1988). Effects of four herbicides on the infestation of maize by nematode Pratylenchus zeae. South African Journal of Plant and Soil, 5(3), 164-165. https://doi.org/10.1080/02571862.1988.10634281

Jordaan, E. M., Waele, D., \& Rooyen, P. J. V. (1989). Endoparasitic nematodes in maize roots in the western Transvaal as related to soil texture and rainfall. Journal of Nematology, 21(3), 356-360. https://www.ncbi.nlm.nih.gov/pmc/articles/PMC2618944/

Levene, B. C. (1995). Response of soybean cyst nematodes to herbicide application on soybeans. 89 p. Dissertation (Doctor of Philosophy in Crop Production and Physiology). Iowa State University, Ames: Iowa/United States of America. https://lib.dr.iastate.edu/cgi/viewcontent.cgi?article=12009\&context=rtd

Macedo, L. B. (2012). Efeito de herbicidas sobre a densidade populacional de Pratylenchus brachyurus em cultivares de soja. 51 p. Dissertation (Pós Graduação em Agronomia). Goiânia: Universidade Federal de Goiás. https://repositorio.bc.ufg.br/tede/handle/tede/3465 
Maciel, C. D. G., Zobiole, L. H. S., Souza, J. I. S., Hirooka, E., Lima, L. G. N. V., Soares, C. R. B., Pivatto, R. A. D., Fuchs, G. M., \& Helvig, E. O. (2013). Eficácia do herbicida haloxyfop R (GR-142) isolado e associado a 2,4-D no controle de híbridos de milho $\mathrm{RR}^{\circledR}$ voluntário. Revista Brasileira de Herbicidas, 12(2), 112-123. https://doi.org/10.7824/rbh.v12i2.244

Marcon, J. E. L. (2015). Misturas em tanque de herbicidas como estratégias de manejo de plantas daninhas resistentes ao glyphosate na cultura da soja $R R^{\circledR} .54$ p. Dissertation (Pós Graduação em Ciências Agrárias). Umuarama: Universidade Estadual de Maringá. p. 54

Matias, J. P., Silva, A. A. P., Helvig, E. O., Maciel, C. D. G., Dias-Arieira, C. R., \& Karam, D. (2018). Suscetibilidade de milho, soja e capim amargoso ao nematoide das lesões radiculares. Revista Brasileira de Milho e Sorgo, 17(2), 353-358. https://doi.org/10.18512/1980-6477/rbms.v17n2p353-358

McDonald, A. H., \& Van Den Berg, E. H. (1993). Effect of watering regime on injury to corn and grain sorghum by Pratylenchus species. Journal of Nematology, 25(4), 654-658. Retrieved from https://www.ncbi.nlm.nih.gov/pmc/articles/PMC2619429/

Melo, M. S. C., Rosa, L. E., Brunharo, C. A. C. G., Nicolai, M., \& Christoffoleti, P. J. (2012). Alternativas para o controle químico de capim-amargoso (Digitaria insularis) resistente ao glyphosate. Revista Brasileira de Herbicidas, 11(2), 195-203. https://doi.org/10.7824/rbh.v11i2.145

Nelson, K. A., Johnson, W. G., Wait, J. D., \& Smoot, R. L. (2006). Winter-annual weed management in corn (Zea mays) and soybean (Glycine max) and the impact on soybean cyst nematode (Heterodera glycines) egg population densities. Weed Technology, 20(4), 965-970. https://doi.org/10.1614/WT-05-119.1

Nicolai, M., \& Christoffoleti, P. J. (2016). Aspectos gerais do manejo de plantas daninhas resistentes a herbicidas nos sistemas de produção envolvendo as culturas de milho e soja. In P. J. Christoffoleti, \& M. Nicolai (Eds), Aspectos de resistência de plantas daninhas a herbicidas (pp. 229-235). Piracicaba: HRAC-BR.

Oostenbrink, R. (1966). Major characteristics of the relation between nematodes and plants. Mededeelingen der Landbouw-Hoogeschool, 66(3), 1-46.

Pereira, G. R., Costa, N. V., Moratelli, G., \& Rodrigues-Costa, A. C. P. (2017). Growth and development of Digitaria insularis biotypes susceptible and resistant to glyphosate. Planta Daninha, 35, e017160505. https://doi.org/10.1590/S0100-83582017350100025

Pimentel-Gomes, F. (2009). Curso de estatística experimental. Piracicaba: FEALQ. p. 451p.

Queiróz, C. A., Fernandes, C. D., Verzignassi, J.R., Valle, C. B., Mallmann, G., \& Batista, M. V. (2014). Reação de acessos e cultivares de Brachiaria spp. e Panicum maximum à Pratylenchus brachyurus. Summa Phytopathologica, 40(3), 226-230. https://doi.org/10.1590/0100-5405/1899

Riboldi, L. B., Aguillera, M. M., \& Monquero, P. A. (2013). Efeito da aplicação de herbicidas 
dessecantes na soja sobre as populações de nematoides no solo. Semina: Ciências Agrárias, 34(6), 3577-3584. https://doi.org/10.5433/1679-0359.2013v34n6Supl1p3577

Roman, E. S., Berckie, H., Vargas, L., Hall, L., Rizzardi, M. A., \& Wolf, T. M. (2007). Como funcionam os herbicidas: da biologia à aplicação. Passo Fundo: Editora Berthier.

SBCPD - Sociedade Brasileira da Ciência das Plantas Daninhas. (1995). Procedimentos para instalação, avaliação e análise de experimentos com herbicidas. Londrina: SBCPD.

Trezzi, M. M., Mattei, D., Vidal, R. A., Kruse, N. D., Gustman, M. S., Viola, R., Machado, A., \& Silva, H. L. (2007). Antagonismo das associações de clodinafop-propargyl com metsulfurom-methyl e 2,4-D no controle de azevém (Lolium multiflorum). Planta Daninha, 25(4), 839-847. https://doi.org/10.1590/S0100-83582007000400021

Ulguim, A. R., Perboni, L. T., Westendorff, N. R., Nohatto, M. A., Silva, B. M., \& Agostinetto, D. (2013). Redução do espaçamento entrelinhas do milho e sua influência na dose do herbicida. Revista Brasileira de Herbicidas, 12(3), 232-241. https://doi.org/10.7824/rbh.v12i3.210

Vieira Jr, N. S., Jakelaitis, A., Cardoso, I. S., Rezende, P. N., Moraes, N. C., Araújo, V. T., \& Tavares, C. J. (2015). Associação de herbicidas aplicados em pós-emergência na cultura do milho. Global Science and Technology, $8(1), \quad$ 1-8. https://doi.org/10.14688/1984-3801/gst.v8n1p1-8

Werle, R., Bernards, M. L., Giesler, L. J., \& Lindquist, J. L. (2013). Influence of two herbicides on soybean cyst nematode (Heterodera glycines) reproduction on henbit (Lamium amplexicaule ) $\quad$ roots. Weed Technology, 27(1), 41-46. https://doi.org/10.1614/WT-D-12-00094.1

Wong, A. T. S., Tylka, G. L., \& Hartzler, R. G. (1993). Effects of eight herbicides on in vitro hatching of Heterodera glycines. Journal of Nematology, 25(4), 578-584. Retrieved from https://www.ncbi.nlm.nih.gov/pmc/articles/PMC2619426/pdf/578.pdf

Zagonel, J., Fernandes, E. C., Ferreira, C. (2010). Períodos de convivência e programas de controle de plantas daninhas em simulação de milho resistente a glifosato. In Congresso Brasileiro da Ciência das Plantas Daninhas, Resumos Expandidos (pp. 1854-1858). Ribeirão Preto: SBCPD.

\section{Copyright Disclaimer}

Copyright for this article is retained by the author(s), with first publication rights granted to the journal.

This is an open-access article distributed under the terms and conditions of the Creative Commons Attribution license (http://creativecommons.org/licenses/by/4.0/). 